\title{
Model Matematika SIR Sebagai Solusi Kecanduan Penggunaan Media Sosial
}

\author{
Syafruddin Side ${ }^{1, \text { a) }}$, Wahidah Sanusi ${ }^{1, \text { b) }}$, dan Nur Khaerati Rustan ${ }^{1, c)}$ \\ ${ }^{1}$ Jurusan Matematika, Fakultas Matematika dan Ilmu Pengetahuan Alam \\ Universities Negeri Makassar \\ a) syafruddin@unm.ac.id \\ b)wahidah.sanusi@unm.ac.id \\ c)nurkhaeratirustan@gmail.com
}

\begin{abstract}
Abstrak. Penelitian ini bertujuan untuk membangun model SIR (Susceptible - Infected - Recovered) sebagai solusi kecanduan penggunaan media sosial dengan asumsi bahwa mahasiswa yang sembuh dari kecanduan media sosial karena memiliki kontrol diri tinggi. Model ini dibagi menjadi tiga kelas yaitu kelas mahasiswa yang berpotensi menggunakan media sosial, kelas mahasiswa yang kecanduan media sosial, dan kelas mahasiswa yang memiliki kontrol diri tinggi. Data yang digunakan adalah data primer yang diperoleh dengan membagikan kuesioner kepada 145 mahasiswa Jurusan Matematika FMIPA UNM angkatan 2017, 2018, dan 2019. Hasil data riil model tipe SIR menghasilkan bilangan reproduksi dasar $\left(R_{0}\right)$ sebesar 1.451136 yang berarti bahwa jumlah mahasiswa yang kecanduan penggunaan media sosial akan meningkat dalam kurun waktu tertentu.
\end{abstract}

Kata Kunci: Titik Ekuilibrium, Bilangan Reproduksi Dasar, Media Sosial, Kontrol Diri, Model SIR

\begin{abstract}
This study aims to build the SIR (Susceptible - Infected - Recovered) model as a solution of social media addiction with the assumption that students who recover from addiction of social media because they have high selfcontrol. This model is divided into three classes: namely class of students who have potential to use social media, class of students who are addicted to social media, and class of students who have high selfcontrol. The data used are primary data that was obtained by distributing questionnaires to 145 students of mathematics departement FMIPA UNM class of 2017, 2018, and 2019. The simulation results of the SIR type model produce a basic reproduction number $\left(R_{0}\right)$ of 1.451136 which means that the number of students who are addicted to the use of social media will increase in a certain period of time.
\end{abstract}

Keywords: Equilibrium Points, Basic Reproduction Numbers, Social Media, Selfcontrol, SIR Model

\section{PENDAHULUAN}

Model matematika adalah hubungan antara komponen-komponen dalam suatu masalah yang dirumuskan dalam suatu persamaan matematik, yang memuat komponen-komponen itu sebagai variabelnya. Proses untuk memperoleh model dari suatu masalah disebut pemodelan matematika (Side \& Rangkuti, 2015). Model matematika sekarang ini banyak digunakan dalam bidang kesehatan. Seperti model matematika untuk menganalisis penyebaran penyakit diantaranya ada model epidermi SIR (Susceptible-Infected-Recovered), SEIR (Susceptible-Exposed-InfectedRecovered), dan lainnya (Putra, 2011). 
Pada model SIR, populasi manusia dibagi menjadi tiga kelompok, yaitu susceptible merupakan individu yang tidak terinfeksi tetapi golongan ini dapat tertular penyakit. Oleh karena itu, golongan ini memiliki kemungkinan untuk menjadi terinfeksi. Infected merupakan individu yang dapat menyebarkan penyakit pada individu yang rentan. Waktu yang diperlukan oleh penderita terinfeksi penyakit dinamakan periode penyakit, setelah mengalami periode penyakit kemudian individu ini pindah dan menjadi individu yang sembuh atau recovered. Sedangkan recovery merupakan individu yang telah sembuh atau kebal dari penyakit (Side \& Rangkuti, 2013). Selain digunakan dibidang kesehatan model SIR juga dapat digunakan dibidang sosial salah satunya untuk melihat tingkat penyebaran kecanduan penggunaan media sosial.

Media sosial adalah sebuah kelompok aplikasi berbasis internet yang dibangun atas dasar teknologi Web 2.0 dan mendukung penciptaan serta pertukaran usergenerated content, juga memungkinkan penggunanya untuk berpartisipasi dalam berbagai komunikasi dan dikemas dalam bentuk yang beragam, baik blog, jejaring sosial, forum, wiki dan lain-lain (Kaplan \& Haenlein, 2010). Data yang diperoleh dari APJII (Asosiasi Penyelenggara Jasa Internet Indonesia) pada tahun 2018 terdapat 171,17 juta pengguna internet di Indonesia dengan jumlah penduduk mencapai angka 265,16 juta jiwa, ini berarti $64,8 \%$ penduduk Indonesia adalah pengguna internet (APJII, 2018).

Penggunaan media sosial banyak membantu dalam kehidupan sehari-hari, akan tetapi jika penggunaannya berlebihan dapat menimbulkan kecanduan. Kecanduan internet karena penggunaan media sosial yang berlebihan dapat menyebabkan gangguan psikologis dimana penggunanya menambah jumlah penggunaan. Dampak yang ditimbulkan dapat membangkitkan kesenangan yang menimbulkan termor, kecemasan, perubahan mood, gangguan afeksi (depresi, sulit menyesuaikan diri), dan terganggunya kehidupan sosial (menurun atau hilang sama sekali, baik dari segi kualitas maupun kuantitas) (Nurmandia, Wigati, \& Maslucha, 2013).

Salah satu solusi dari kecanduan penggunaan media sosial adalah dengan adanya kontrol diri dalam menggunakan media sosial. Setiap individu memiliki suatu mekanisme yang dapat membantu mengatur dan mengarahkan perilaku yaitu kontrol diri. Sebagai salah satu sifat kepribadian, kontrol diri pada suatu individu dengan individu yang lain tidaklah sama. Ada individu yang memiliki kontrol diri yang tinggi dan ada individu yang memiliki kontrol diri yang rendah. Individu yang memiliki kontrol diri tinggi mampu mengubah kejadian dan menjadi agen utama dalam mengarahkan dan mengatur perilaku yang membawa pada konsekuensi positif (Widiana, Retnowati, \& Hidayat, 2004).

Beberapa peneliti telah mengkaji permasalahan mengenai pemodelan matematika terkait bidang penyakit dan penggunaan media sosial. Diantaranya penelitian yang dilakukan oleh Side (2015) "A Susceptible-Infected-Recovered Model and Simulation for Transmission of Tuberculosis", Leleury, Lesnussa, Bension dan Kakisina (2017) "Analisis Stabilitas Model SIR (Susceptible, Infected, Recovered) pada Penyebaran Penyakit Demam Berdarah Dengue di Provinsi Maluku", Hartinah, Sriati, dan Kosasih (2019) "Gambaran Tingkat Gejala Kecanduan Media Sosial pada Mahasiswa Keperawatan Universitas Padjajaran" dan penelitian yang dilakukan oleh Muna dan Astuti (2014) "Hubungan Antara Kontrol Diri dengan Kecenderungan Kecanduan Media Sosial pada Remaja Akhir". Maka pada penelitian ini akan mengkombinasikan penelitian tersebut dengan judul "Model Matematika SIR Sebagai Solusi Kecanduan Penggunaan Media Sosial".

\section{KAJIAN PUSTAKA}

\section{Sistem Persamaan Diferensial Biasa}

Persamaan diferensial biasa adalah persaman yang memuat turunan terhadap fungsi yang memuat satu variabel bebas. Jika $x$ adalah fungsi dari t (Campbell \& Haberman, 2008). Berikut adalah contoh persamaan diferensial biasa dalam persamaan (1). 


$$
\frac{d x}{d t}=t^{2}+\cos x
$$

\section{Sistem Persamaan Diferensial}

Sistem persamaan diferensial adalah suatu sistem yang memuat $n$ buah persamaan diferensial, dengan $n$ buah fungsi yang tidak diketahui, dimana $n$ merupakan bilangan bulat positif lebih besar sama dengan dua. Antara persamaan diferensial yang satu dengan yang lain saling berkaitan dan konsisten. Bentuk umum dari suatu sistem $n$ persamaan orde pertama mempunyai bentuk sebagai berikut:

$$
\begin{gathered}
\frac{d x_{1}}{d t}=g_{1}\left(t, x_{1}, x_{2}, \ldots, x_{n}\right) \\
\frac{d x_{2}}{d t}=g_{2}\left(t, x_{1}, x_{2}, \ldots, x_{n}\right) \\
\vdots \\
\frac{d x_{n}}{d t}=g_{n}\left(t, x_{1}, x_{2}, \ldots, x_{n}\right)
\end{gathered}
$$

dengan $x_{1}, x_{2}, \ldots, x_{n}$ adalah variabel bebas dan $t$ adalah variabel terikat, sehingga $x_{1}=$ $x_{1}(t), x_{2}=x_{2}(t), \ldots, x_{n}=x_{n}(t)$, dimana $\frac{d x_{n}}{d t}$ merupakan sebuah derivatif fungsi $x_{n}$ terhadap $t$, dan $g_{1}$ adalah fungsi yang tergantung pada variabel $x_{1}, x_{2}, \ldots, x_{n}$ dan $t$ (Neuhauser, 2004).

\section{Titik Ekuilibrium}

Titik ekuilibrium adalah sebuah keadaan dari suatu sistem yang tidak berubah terhadap waktu. Jika sistem dinamika diuraikan dalam sebuah persamaan diferensial, maka titik ekuilibrium dapat diperoleh dengan mengambil turunan pertama yang sama dengan nol (Haberman, 1997). Haberman (1997) menyatakan bahwa titik $\bar{x} \in R^{n}$ disebut titik kesetimbangan (equilibrium point) dari $\dot{x}=f(x)$ jika memenuhi $f(x)=0$, dimana

$$
f(x)=\left[\begin{array}{c}
f_{1}\left(x_{1}, x_{2}, \ldots, x_{n}\right) \\
f_{2}\left(x_{1}, x_{2}, \ldots, x_{n}\right) \\
\vdots \\
f_{n}\left(x_{1}, x_{2}, \ldots, x_{n}\right)
\end{array}\right]
$$

Misalkan diberikan suatu persamaan diferensial yang berbentuk

$$
\begin{aligned}
& \frac{d x}{d t}=f(x, y) \\
& \frac{d y}{d t}=g(x, y)
\end{aligned}
$$

sebuah titik $\left(x_{0}, y_{0}\right)$ dapat dikatakan sebagai titik ekuilibrium dari sistem (3). Apabila dipenuhi syarat $f\left(x_{0}, y_{0}\right)=0$ dan $g\left(x_{0}, y_{0}\right)=0$. Karena turunan suatu konstanta sama dengan nol, maka sepasang fungsi konstanta $x(t)=x_{0}$ dan $y(t)=y_{0}$ merupakan penyelesaian keseimbangan dari sistem (3) (Campbell dan Haberman, 2008).

\section{Linearisasi}

Linearisasi adalah proses hampiran persamaan diferensial nonlinear dengan persamaan diferensial linear. Misalkan diberikan sistem persamaan diferensial biasa nonlinear berikut:

$$
\dot{x}=f(x), x \in R^{n}
$$

dengan $x(t) \in R^{n}$ adalah suatu fungsi bernilai vektor dalam $t$ dan $f: U \rightarrow R^{n}$ adalah suatu fungsi mulus yang terdefinisi pada subhimpunan $U \subset R^{n}(\mathrm{Tu}, 1994)$. 
Dengan menggunakan ekspansi Taylor disekitar titik ekuilibrium, maka sistem persamaan (4) dapat ditulis sebagai berikut:

$$
\dot{x}=\dot{\eta}=J \eta+\varphi(\eta)
$$

dengan $J$ adalah matriks Jacobi yang dinyatakan sebagai berikut:

$$
J(x)=\left(\begin{array}{ccc}
\frac{\partial f_{1}}{\partial x_{1}} & \cdots & \frac{\partial f_{m}}{\partial x_{n}} \\
\vdots & \ddots & \vdots \\
\frac{\partial f_{m}}{\partial x_{1}} & \cdots & \frac{\partial f_{m}}{\partial x_{n}}
\end{array}\right)
$$

dan $\varphi(\eta)$ adalah suku berorde tinggi yang bersifat $\lim _{\eta \rightarrow 0} \varphi(\eta)=0$, dengan $\eta=x-\bar{x}$. J $\eta$ pada sistem persamaan (4) disebut pelinearan sistem persamaan (5) (Tu, 1994).

\section{Nilai Eigen dan Vektor Eigen}

Jika $A$ adalah suatu matriks berordo $n x n$, maka vektor tak nol $x$ pada $R^{n}$ disebut suatu vektor eigen (eigen vector) dari $A$ jika $A x$ adalah suatu penggandaan skalar $x$ yaitu:

$$
A x=\lambda x
$$

untuk skalar $\lambda$. Skalar $\lambda$ disebut nilai eigen dari $A$ dan $x$ suatu vektor eigen yang bersesuaian dengan nilai eigen $\lambda$ (Side, 2013). Untuk mencari kembali nilai eigen dari suatu matriks yang berukuran $n x n$, maka kita tuliskan kembali persamaan (6) sebagai berikut.

$$
A x=\lambda I x \text { atau }(A-I \lambda) x=0
$$

\section{Kestabilan Titik Ekuilibrium}

Konsep perilaku sistem pada titik ekuilibrium dikenal sebagai kestabilan titik kesetimbangan. Kestabilan tersebut merupakan informasi untuk menggambarkan perilaku sistem.

Kestabilan titik ekuilibrium $\bar{x}$ dapat ditentukan dengan memperhatikan nilai-nilai eigen, yaitu $\lambda_{i}$ dimana $i=1,2, \ldots, n$ yang diperoleh dari persamaan karakteristik. Secara umum kestabilan titik mempunyai perilaku sebagai berikut:

1. Stabil, jika:

a) Setiap nilai eigen real adalah negatif ( $\lambda_{i}<0$ untuk semua $i$ )

b) Setiap komponen bagian real dari nilai eigen kompleks, lebih kecil atau sama dengan nol $\left(\operatorname{Re}\left(\lambda_{i}\right) \leq 0\right.$ untuk semua $\left.i\right)$

2. Tidak stabil, jika:

a) Terdapat nilai eigen real adalah positif ( $\lambda_{i}>0$ untuk semua $i$ ).

b) Ada komponen bagian real dari nilai eigen kompleks, lebih besar dari nol $\left(\operatorname{Re}\left(\lambda_{i}\right)>\right.$ 0 untuk semua $i$ ).

3. Sadel atau pelana, jika perkalian dua buah nilai eigen real sembarang adalah negatif $\left(\lambda_{i} \lambda_{j}<0\right.$ untuk $i$ dan $j$ sembarang). Titik ekuilibrium sadel ini bersifat tak stabil ( $\mathrm{Tu}$, 1994).

4. Jika salah satu nilai eigen yang diperoleh bernilai nol $\left(\lambda_{1}=0, \lambda_{2} \neq 1\right)$ maka titik ekuilibriumnya akan berada dalam suatu garis. Jika $\lambda_{2}<0$ maka solusi yang tidak dimulai dari titik tetap ini cenderung untuk bergerak menuju garis tersebut. Dan sebaliknya, jika $\lambda_{2}>0$ maka akan bergerak menjauhi garis tersebut (Farlow,1994). 


\section{Bilangan Reproduksi Dasar}

Bilangan reproduksi dasar merupakan bilangan yang menunjukkan jumlah individu rentan yang dapat menderita penyakit yang disebabkan oleh satu individu terinfeksi (Giesecke, 1994). Bilangan reproduksi dasar dilambangkan dengan $R_{0}$ dengan beberapa kondisi yang akan timbul, yaitu:

1. Jika $R_{0}<1$, maka penyakit akan menghilang.

2. Jika $R_{0}=1$, maka penyakit akan menetap.

3. Jika $R_{0}>1$, maka penyakit akan meningkat menjadi wabah.

\section{Kecanduan Media Sosial}

Kecanduan internet karena penggunaan media sosial yang berlebihan dapat menyebabkan gangguan psikologis dimana penggunanya menambah jumlah penggunaan. Dampak yang ditimbulkan dapat membangkitkan kesenangan yang menimbulkan termor, kecemasan, perubahan mood, gangguan afeksi (depresi, sulit menyesuaikan diri), dan terganggunya kehidupan sosial (menurun atau hilang sama sekali, baik dari segi kualitas maupun kuantitas) (Nurmandia, dkk, 2013).

Kriteria seseorang dapat disebut sebagai pecandu media sosial salah satunya adalah penggunaan yang berlebihan. Penggunaan internet karena media sosial yang berlebihan dapat dilihat pada intensitas dan frekuensi penggunaan internet sehingga membentuk perilaku kecanduan (Horrigan, 2002). Menurut Surya dalam The Graphic, Visualizatio \& Usability Center, The George Institute of Techology (Rochmawati, 2012) menggolongkan pengguna internet ke dalam tiga tahapan berdasarkan intensitas yaitu:

1. Heavy User (lebih dari 40 jam per bulan) atau sekitar 6 jam per hari.

2. Medium User (lebih dari 10-40 jam per bulan) atau 3-6 jam per hari.

3. Light User (lebih dari 10 jam per bulan) atau kurang dari 3 jam per hari.

\section{METODE PENELITIAN}

Penelitian ini merupakan penelitian terapan dengan pendekatan kuantitatif yaitu dengan mengambil atau mengumpulkan data yang diperlukan. Data yang digunakan adalah data primer yang diperoleh dengan membagikan kuesioner kepada 145 mahasiswa Jurusan Matematika FMIPA UNM angkatan 2017, 2018, dan 2019.

Adapun prosedur penelitian yang diterapkan pada penelitian ini sebagai berikut:

1. Membangun model SIR kecanduan penggunaan media sosial.

2. Menganalisis model SIR kecanduaan penggunaan media sosial.

3. Melakukan simulasi model SIR kecanduan penggunaan media sosial menggunakan software Maple 18.

4. Memberikan solusi berupa rekomendasi kepada mahasiswa dalam upaya untuk mengatasi jumlah mahasiswa yang kecanduan media sosial. Berdasarkan hasil simulasi model berupa grafik prediksi kasus kecanduan media sosial beberapa waktu mendatang.

\section{HASIL DAN PEMBAHASAN}

\section{Model Matematika SIR Sebagai Solusi Kecanduan Penggunaan Media Sosial}

Dalam penelitian ini terdapat beberapa asumsi yang digunakan untuk memodelkan kecanduan media sosial, yaitu: 
1. Sampel yang digunakan adalah mahasiswa aktif Jurusan Matematika FMIPA UNM angkatan 2017, 2018 dan 2019 yang memiliki media sosial.

2. Diasumsikan bahwa jumlah mahasiswa yang menggunakan media sosial sama dengan jumlah mahasiswa yang berhenti menggunakan media sosial.

3. Mahasiswa yang berpotensi kecanduan media sosial yaitu mahasiswa yang menggunakan media sosial.

4. Mahasiswa yang kecanduan media sosial merupakan mahasiswa yang mengakses media sosial total 6 jam atau lebih dalam sehari.

5. Mahasiswa yang telah sembuh dari kecanduan penggunaan media sosial yaitu mahasiswa yang memiliki kontrol diri tinggi.

6. Populasi konstan (tertutup), artinya

$$
\boldsymbol{N}=(\boldsymbol{S}(\boldsymbol{t}))+(\boldsymbol{I}(\boldsymbol{t}))+(\boldsymbol{R}(\boldsymbol{t}))
$$

Berdasarkan asumsi maka diperoleh model SIR untuk kecanduan media sosial dalam bentuk diagram transfer yang dapat dilihat pada Gambar 1 berikut.

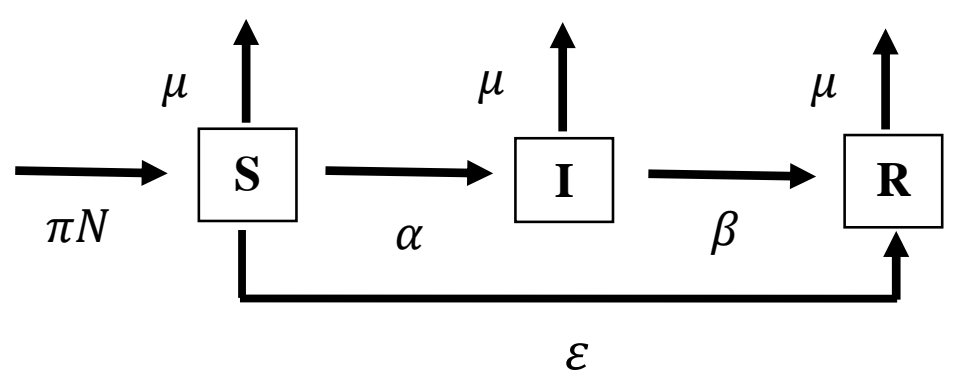

GAMBAR 1. Diagram transfer model matematika SIR kecanduan penggunaan media sosial

Adapun penjelasan dari Gambar 1 dapat dilihat pada Tabel 1.

TABEL 1. Penjelasan Variabel/Parameter

\begin{tabular}{cl}
\hline Variabel/Parameter & \multicolumn{1}{c}{ Keterangan } \\
\hline$S(t)$ & Jumlah mahasiswa yang berpotensi kecanduan media sosial \\
$I(t)$ & Jumlah mahasiswa yang kecanduan media sosial \\
$R(t)$ & Jumlah mahasiswa yang memiliki kontrol diri tinggi \\
$\mathrm{N}$ & $\begin{array}{l}\text { Total sampel mahasiswa aktif jurusan Matematika FMIPA } \\
\text { UNM angkatan 2017, 2018, dan 2019 } \\
\pi\end{array}$ \\
$\begin{array}{l}\text { Laju mahasiswa yang menggunakan media sosial } \\
\text { Laju mahasiswa yang berhenti menggunakan media sosial } \\
\beta\end{array}$ & $\begin{array}{l}\text { Laju mahasiswa yang mengakses media sosial total } 6 \text { jam atau } \\
\text { lebih dalam sehari } \\
\text { Laju mahasiswa yang sembuh dari kecanduan media sosial } \\
\text { dengan kontrol diri tinggi } \\
\text { Laju mahasiswa yang memiliki kontrol diri tinggi }\end{array}$ \\
\hline
\end{tabular}


Berdasarkan asumsi dan hubungan antara variabel dan parameter pada Gambar 1 dapat dijelaskan pada persamaan berikut:

$$
\begin{aligned}
& \frac{d S}{d t}=\pi N-(\mu+\alpha+\varepsilon) S \\
& \frac{d I}{d t}=\alpha S-(\mu+\beta) I \\
& \frac{d R}{d t}=\varepsilon S+\beta I-\mu R
\end{aligned}
$$

dengan $\mathrm{N}=(\mathrm{S}(\mathrm{t})+\mathrm{I}(\mathrm{t})+\mathrm{R}(\mathrm{t}))$ adalah total sampel.

\section{Analisis Model Matematika SIR Menggunakan Data Kecanduan Penggunaan Media Sosial}

TABEL 2. Data awal

\begin{tabular}{cc}
\hline Variabel & Nilai \\
\hline $\mathrm{S}(0)$ & 40 \\
$\mathrm{I}(0)$ & 68 \\
$\mathrm{R}(0)$ & 37 \\
$\mathrm{~N}$ & 145 \\
\hline
\end{tabular}

TABEL 3. Parameter model SIR kecanduan penggunaan media sosial

\begin{tabular}{cc}
\hline Parameter & Nilai \\
\hline $\mathrm{N}$ & 145 \\
$\pi$ & 0.96 \\
$\mu$ & 0.96 \\
$\alpha$ & 0.51 \\
$\varepsilon$ & 0.17 \\
$\beta$ & Diasumsikan $\beta=0.04$ \\
\hline
\end{tabular}

Sehingga didapatkan formulasi model SIR kecanduan penggunaan media sosial sebagai berikut.

$$
\begin{aligned}
& \frac{d s}{d t}=\pi-(\mu+\alpha+\varepsilon) s=0.96-(0.96+0.51+0.17) s \\
& \frac{d i}{d t}=\alpha s-(\mu+\beta) i=0.51 s-(0.96+0.04) i \\
& \frac{d r}{d t}=\varepsilon s+\beta i-\mu r=0.17 s+0.04 i-0.96 r
\end{aligned}
$$

\section{Titik Ekuilibrium}

1. Titik ekuilibrium bebas kecanduan $E_{0}=\left(\frac{\pi}{\mu}, 0,0\right)$

2. Titik ekuilibrium kecanduan $E_{1}=\left(\frac{\pi}{\mu+\alpha+\varepsilon}, \frac{\alpha \pi}{(\mu+\beta)(\mu+\alpha+\varepsilon)}, \frac{\pi(\alpha \beta+\beta \varepsilon+\varepsilon \mu)}{\mu(\mu+\beta)(\mu+\alpha+\varepsilon)}\right)$ 


\section{Analisi Kestabilan Titik Ekuilibrium}

Matriks jacobian dari titik ekuilibrium bebas kecanduan.

$$
J E_{0}=\left[\begin{array}{ccc}
-(\mu+\alpha+\varepsilon) & 0 & 0 \\
\alpha & -(\mu+\beta) & 0 \\
\varepsilon & \beta & -\mu
\end{array}\right]
$$

Untuk mengetahui kestabilan $E_{0}$ maka terlebih dahulu dicari nilai eigennya. Jika $\lambda_{i}$ adalah nilai eigen dari $J E_{0}$ maka

$$
\begin{aligned}
& \operatorname{det} \lambda I-J E_{0}=0 \\
& \operatorname{det}\left(\lambda\left[\begin{array}{lll}
1 & 0 & 0 \\
0 & 1 & 0 \\
0 & 0 & 1
\end{array}\right]-\left[\begin{array}{ccc}
-(\mu+\alpha+\varepsilon) & 0 & 0 \\
\alpha & -(\mu+\beta) & 0 \\
\varepsilon & \beta & -\mu
\end{array}\right]\right)=0 \\
& \operatorname{det}\left(\left[\begin{array}{lll}
\lambda & 0 & 0 \\
0 & \lambda & 0 \\
0 & 0 & \lambda
\end{array}\right]-\left[\begin{array}{ccc}
-(\mu+\alpha+\varepsilon) & 0 & 0 \\
\alpha & -(\mu+\beta) & 0 \\
\varepsilon & \beta & -\mu
\end{array}\right]\right)=0 \\
& \operatorname{det}\left(\left[\begin{array}{ccc}
\lambda+\mu+\alpha+\varepsilon & 0 & 0 \\
-\alpha & \lambda+\mu+\beta & 0 \\
-\varepsilon & -\beta & \lambda+\mu
\end{array}\right]\right)=0 \\
& =(\lambda+\mu+\alpha+\varepsilon)(\lambda+\mu+\beta)(\lambda+\mu)+0(-\varepsilon) 0+0(-\alpha)(-\beta)-(0(\lambda+\mu+\beta)(-\varepsilon)+ \\
& (\lambda+\mu+\alpha+\varepsilon) 0(-\beta)+0(-\alpha)(\lambda+\mu)) \\
& =(\lambda+\mu+\alpha+\varepsilon)(\lambda+\mu+\beta)(\lambda+\mu) \\
& \begin{array}{c}
=\lambda^{3}+\lambda^{2}(3 \mu+2 \beta+\alpha)+\lambda\left(3 \mu^{2}+4 \mu \beta+2 \mu \alpha+\beta \alpha+\beta^{2}\right)+\left(\mu^{3}+\mu^{2} \beta+\mu^{2} \alpha+\mu \beta \alpha\right. \\
\left.+\mu \beta+\mu \beta^{2}\right)
\end{array}
\end{aligned}
$$

Sehingga diperoleh nilai eigen sebagai berikut.

$$
\begin{aligned}
& \lambda_{1}=-\mu-\alpha-\varepsilon \\
& \lambda_{2}=-\mu-\beta \\
& \lambda_{3}=-\mu
\end{aligned}
$$

Suatu sistem dikatakan stabil, jika setiap nilai eigen real adalah negatif $\left(\lambda_{i}<0\right)$ untuk semua $i=$ 1,2 dan 3. Karena $\mu, \alpha, \varepsilon$, dan $\beta$ bernilai positif maka $\lambda_{1}$ sampai $\lambda_{3}$ bernilai negatif sehingga titik ekuilibrium bebas kecanduan $E_{0}=\left(\frac{\pi}{\mu}, 0,0\right)$ bersifat stabil.

\section{Bilangan Reproduksi Dasar}

Model matematika SIR sebagai solusi kecanduan penggunaan media sosial memiliki nilai bilangan reproduksi dasar $\left(R_{0}\right)$ yaitu.

$$
R_{0}=\mu^{3}+\mu^{2} \beta+\mu^{2} \alpha+\mu \beta \alpha+\mu \beta+\mu \beta^{2}=1.45113
$$

yang berarti satu mahasiswa terinfeksi rata-rata dapat menularkan kecanduan penggunaan media sosial kepada satu hingga dua orang mahasiswa rentan dalam sampel. Bilangan reproduksi dasar yang diperoleh lebih dari satu menunjukkan bahwa jumlah mahasiswa yang kecanduan penggunaan media sosial akan meningkat dalam kurun waktu tertentu. 


\section{Simulasi Model SIR Menggunakan Maple}

Simulasi untuk model SIR kecanduan penggunaan media sosial menggunakan data asli.

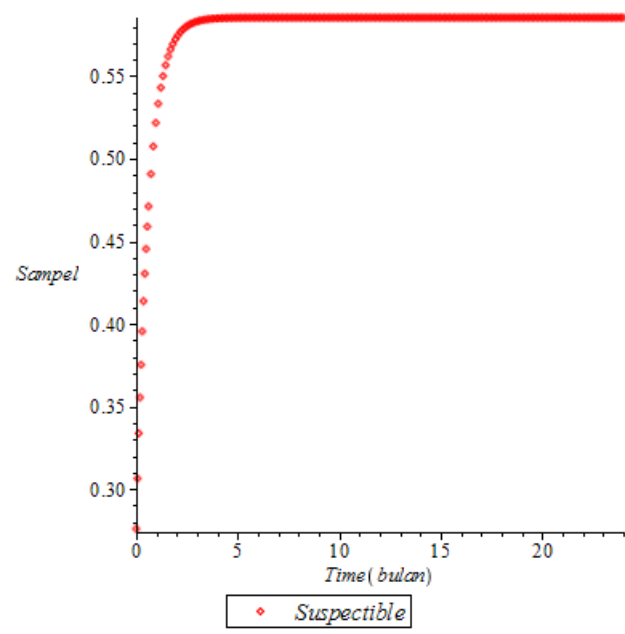

(a)

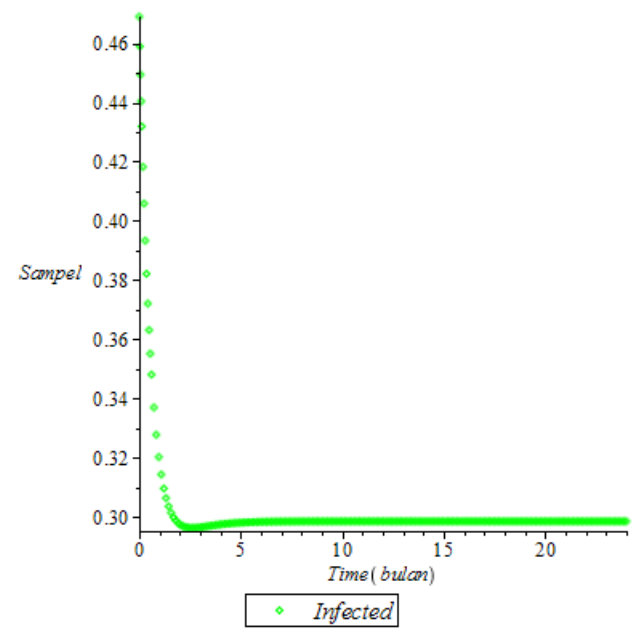

(b)

GAMBAR 2. (a) Plot untuk kelas susceptible

(b) Plot untuk kelas infected

Gambar 2(a) menunjukkan simulasi jumlah mahasiswa yang berpotensi kecanduan media sosial (susceptible) yang terdeteksi setiap bulannya. Jumlah mahasiswa yang berpotensi kecanduan media sosial memerlukan waktu 3 sampai 4 bulan untuk mencapai jumlah tertinggi yaitu 58\% dari jumlah sampel atau sama dengan 85 mahasiswa yang akan rentan kecanduan dari 145 mahasiswa. Pada bulan ke-5 sampai bulan ke-24 tidak mengalami kenaikan atau penurunan jumlah (konstan).

Gambar 2(b) menunjukkan simulasi jumlah mahasiswa yang kecanduan penggunaan media sosial (infected) yang terdeteksi setiap bulannya. Jumlah mahasiswa yang kecanduan penggunaan media sosial mengalami penurunan setiap bulannya dan memerlukan waktu sekitar 3 bulan untuk mencapai jumlah terendah yaitu 29\% dari jumlah sampel atau sama dengan 43 mahasiswa yang akan terinfeksi dari 145 mahasiswa. Pada bulan ke-5 sampai bulan ke-24 tidak mengalami kenaikan atau penurunan jumlah (konstan).

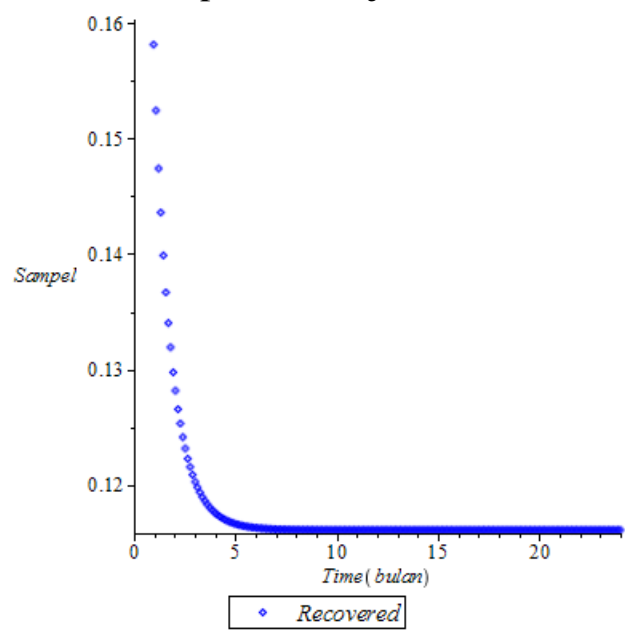

(c)

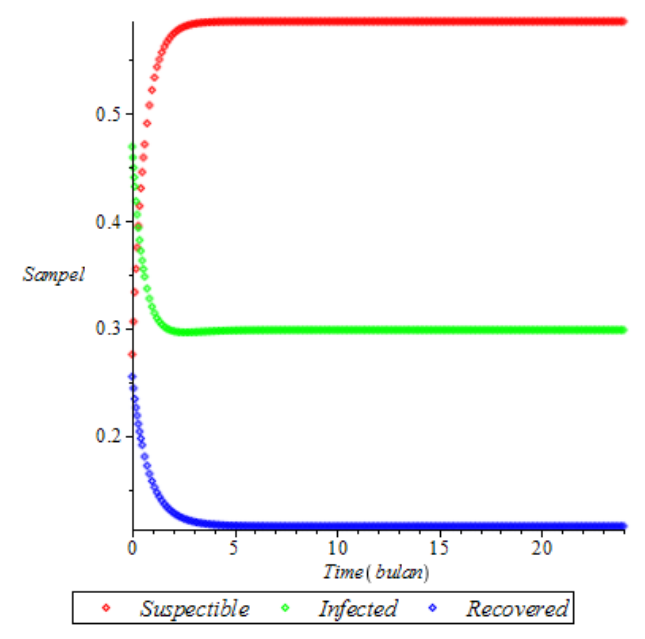

(d)

GAMBAR 3. (c) Plot untuk kelas recovered

(d) Plot model SIR kecanduan penggunaan media sosial 
Gambar (c) menunjukkan simulasi jumlah mahasiswa yang memiliki kontrol diri tinggi (recovered) yang terdeteksi setiap bulannya. Jumlah mahasiswa yang memiliki kontrol diri tinggi mengalami penurunan disetiap bulannya dan memerlukan waktu sekitar 6 bulan untuk mencapai jumlah terendah yaitu $11 \%$ dari jumlah sampel atau sama dengan 17 mahasiswa yang memiliki kontrol diri tinggi dari 145 mahasiswa. Pada bulan ke-10 sampai bulan ke-24 tidak mengalami kenaikan atau penurunan jumlah (konstan).

Gambar (d) menunjukkan bahwa jumlah sampel pada kelas Suspectible memerlukan waktu sekitar 3 sampai 4 bulan untuk mecapai jumlah tertinggi. Untuk jumlah sampel pada kelas Infected mengalami penurunan setiap bulannya dan akan mecapai jumlah terendah pada bulan ke-3. Untuk jumlah sampel pada kelas Recovered mengalami penurunan setiap bulannya dan akan mecapai jumlah terendah pada bulan ke-6. Pada bulan ke-10 sampai bulan ke-24 untuk semua kelas tidak mengalami kenaikan atau penurunan jumlah (konstan).

\section{Model SIR Sebagai Solusi Kecanduan Penggunaan Media Sosial}

Kontrol diri tinggi merupakan salah satu cara untuk mencegah meluasnya kecanduan penggunaan media sosial. Kontrol diri dianggap berhasil jika pada waktu tertentu kecanduan penggunaan media sosial akan menghilang. Dalam hal ini, digunakan simulasi terhadap parameter laju mahasiswa yang sembuh dari kecanduan media sosial dengan kontrol diri tinggi yang disimbolkan dengan $\beta$ untuk mengetahui pengaruh kontrol diri tinggi terhadap kecanduan penggunaan media sosial.

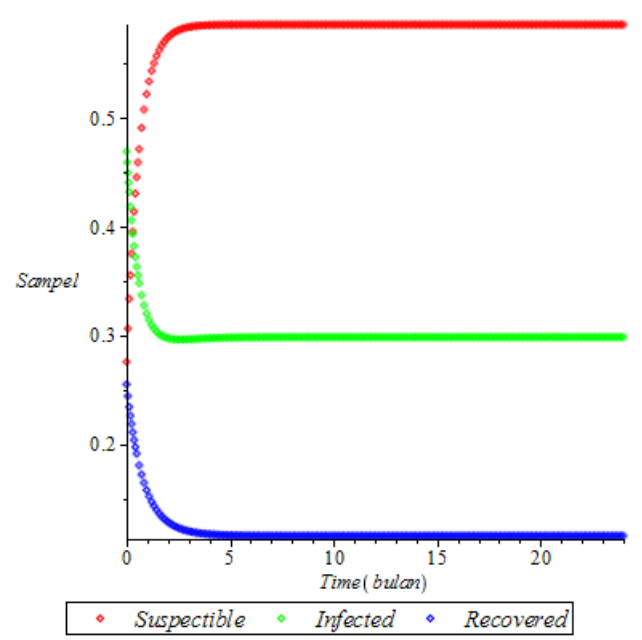

(a)

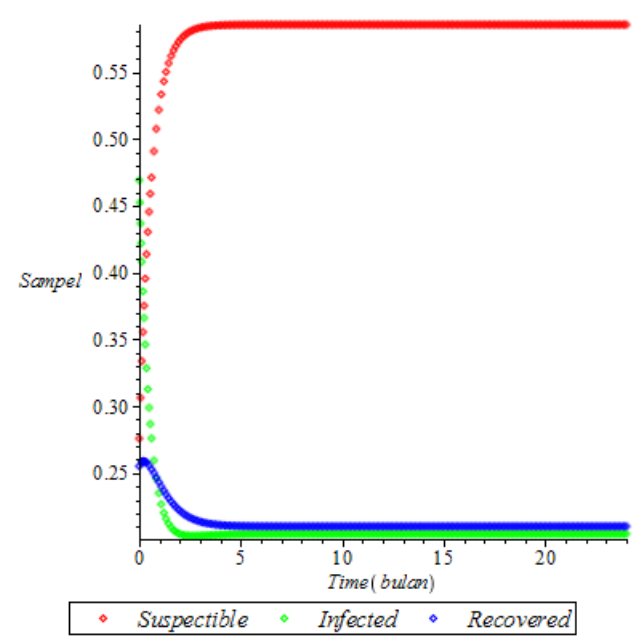

(b)

GAMBAR 4. (a) Plot untuk nilai $\beta=0.04$

(b) Plot untuk nilai $\beta=0.5$

Gambar 4(a) dapat dilihat bahwa pada kelas susceptible jumlah mahasiswa yang berpotensi kecanduan media sosial memerlukan waktu 3 sampai 4 bulan untuk mencapai jumlah tertinggi yaitu 58\% dari jumlah sampel atau sama dengan 85 mahasiswa yang akan rentan kecanduan dari 145 mahasiswa. Pada kelas infected jumlah mahasiswa yang kecanduan penggunaan media sosial mengalami penurunan setiap bulannya dan memerlukan waktu sekitar 3 bulan untuk mencapai jumlah terendah yaitu 29\% dari jumlah sampel atau sama dengan 43 mahasiswa yang akan terinfeksi dari 145 mahasiswa. Pada kelas recovered jumlah mahasiswa yang memiliki kontrol diri tinggi mengalami penurunan disetiap bulannya dan memerlukan waktu sekitar 6 bulan untuk mencapai jumlah terendah yaitu $11 \%$ dari jumlah sampel atau sama dengan 17 mahasiswa yang memiliki kontrol diri tinggi dari 145 mahasiswa.

Gambar 4(b) Untuk nilai $\beta=0.5$ dapat dilihat bahwa pada kelas susceptible jumlah mahasiswa yang berpotensi kecanduan media sosial memerlukan waktu 3 bulan untuk mencapai jumlah 
tertinggi yaitu 58\% dari jumlah sampel atau sama dengan 85 mahasiswa yang akan rentan kecanduan dari 145 mahasiswa. Pada kelas infected jumlah mahasiswa yang kecanduan penggunaan media sosial mengalami penurunan setiap bulannya dan memerlukan waktu sekitar 2 bulan untuk mencapai jumlah terendah yaitu 20\% dari jumlah sampel atau sama dengan 29 mahasiswa yang akan terinfeksi dari 145 mahasiswa. Pada kelas recovered jumlah mahasiswa yang memiliki kontrol diri tinggi mengalami penurunan disetiap bulannya dan memerlukan waktu sekitar 4 bulan untuk mencapai jumlah terendah yaitu $21 \%$ dari jumlah sampel atau sama dengan 31 mahasiswa yang memiliki kontrol diri tinggi dari 145 mahasiswa.

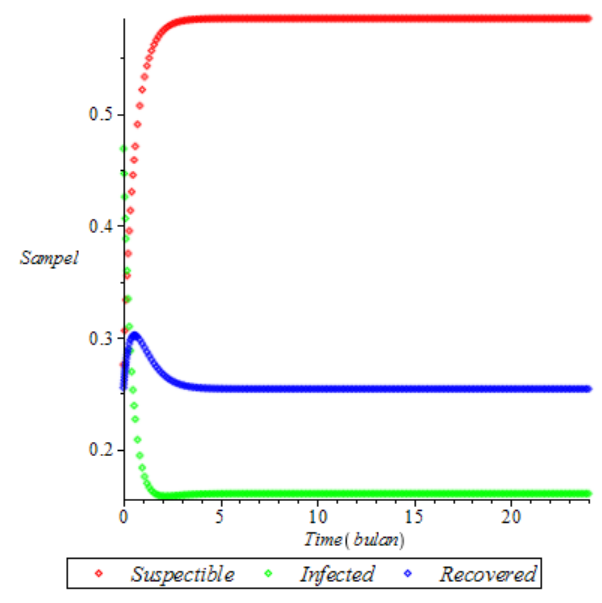

(c)

GAMBAR 5. (c) Plot untuk nilai $\beta=0.9$

Gambar 5(c) dapat dilihat bahwa pada kelas susceptible jumlah mahasiswa yang berpotensi kecanduan media sosial memerlukan waktu 3 untuk mencapai jumlah tertinggi yaitu $58 \%$ dari jumlah sampel atau sama dengan 85 mahasiswa yang akan rentan kecanduan dari 145 mahasiswa. Pada kelas infected jumlah mahasiswa yang kecanduan penggunaan media sosial mengalami penurunan setiap bulannya dan memerlukan waktu sekitar 2 bulan untuk mencapai jumlah terendah yaitu $16 \%$ dari jumlah sampel atau sama dengan 23 mahasiswa yang akan terinfeksi dari 145 mahasiswa. Pada kelas recovered jumlah mahasiswa yang memiliki kontrol diri tinggi mengalami penurunan disetiap bulannya dan memerlukan waktu sekitar 4 bulan untuk mencapai jumlah terendah yaitu 25\% dari jumlah sampel atau sama dengan 37 mahasiswa yang memiliki kontrol diri tinggi dari 145 mahasiswa.

Hasil yang diperoleh dengan nilai parameter $\beta$ yang bervariasi dapat dilihat pada grafik bahwa nilai yang berubah hanya pada kelas infected dan recovered sedangkan nilai dari kelas susceptible tetap. Perbandingannya dapat dilihat pada Tabel 4 berikut.

TABEL 4. Perbandingan hasil dari nilai $\beta$

\begin{tabular}{ccccc}
\hline Nilai $\beta$ & Kelas Susceptible & $\begin{array}{c}\text { Kelas } \\
\text { Infected }\end{array}$ & $\begin{array}{c}\text { Kelas } \\
\text { Recovered }\end{array}$ & $\mathrm{N}$ \\
\hline 0.04 & 85 & 43 & 17 & 145 \\
0.5 & 85 & 29 & 31 & 145 \\
0.9 & 85 & 23 & 37 & 145 \\
\hline
\end{tabular}

Dari Tabel 2 dapat dilihat bahwa jika nilai $\beta$ semakin besar maka jumlah mahasiswa yang kecanduaan penggunaan media sosial akan menurun dan jumlah mahasiswa yang memiliki kontrol diri tinggi akan meningkat dalam kurun waktu tertentu. Akan lebih baik jika nilai $\beta$ dimaksimalkan. 


\section{PENUTUP}

Dari hasil dan pembahasan yang telah dilakukan dapat diperoleh kesimpulan sebagai berikut.

1. formulasi model SIR kecanduan media sosial dalam bentuk persamaan diferensial berikut.

$$
\begin{aligned}
& \frac{d S}{d t}=\pi N-(\mu+\alpha+\varepsilon) S \\
& \frac{d I}{d t}=\alpha S-(\mu+\beta) I \\
& \frac{d R}{d t}=\varepsilon S+\beta I-\mu R
\end{aligned}
$$

2. Model SIR kecanduan penggunaan media sosial diperoleh hasil sebagai berikut.

a. Titik ekuilibrium bebas kecanduan $E_{0}=\left(\frac{\pi}{\mu}, 0,0\right)$

b. Titik ekuilibrium kecanduan $E_{1}=\left(\frac{\pi}{\mu+\alpha+\varepsilon}, \frac{\alpha \pi}{(\mu+\beta)(\mu+\alpha+\varepsilon)}, \frac{\pi(\alpha \beta+\beta \varepsilon+\varepsilon \mu)}{\mu(\mu+\beta)(\mu+\alpha+\varepsilon)}\right)$

3. Hasil simulasi model SIR kecanduan penggunaan media sosial dapat disimpulkan bahwa a) Jumlah mahasiswa yang berpotensi kecanduan media sosial yaitu 85 mahasiswa dari 145 mahasiswa, b) Jumlah mahasiswa yang kecanduan penggunaan media sosial yaitu 43 dari 145 mahasiswa, c) Jumlah mahasiswa yang memiliki kontrol diri tinggi yaitu 17 mahasiswa dari 145 mahasiswa.

4. Model SIR sebagai solusi kecanduan penggunaan media sosial dapat digunakan untuk mengatasi permasalahan kecanduan penggunaan media sosial dengan meningkatkan jumlah mahasiswa yang sembuh dari kecanduan media sosial menggunakan kontrol diri tinggi.

\section{DAFTAR PUSTAKA}

APJII. (2018). Laporan survei penetrasi profil perilaku pengguna internet Indonesia. Jakarta: Asosiasi Penyelenggara Jasa Internet Indonesia.

Campbell, S. L., \& Haberman, R. (2008). Introduction to differential equations with dynamical system. New Jersey: Princeton University Press.

Farlow, S. J. (1994). an introduction to differential equations and their applications. New York: Mc. Graw-Hill Inc.

Giesecke, J. (1994). Modern infectious disease epidemologi. New York: Oxford University Press.

Haberman, R. (1997). Mathematical models: an introduction to applied mathematics. Texas: Prentice-Hall Inc.

Hartinah, S., Sriati, A., \& Kosasih, C. E. (2019). Gambaran tingkat gejala kecanduan media sosial pada mahasiswa keperawatan Universitas Padjajaran. Jurnal Keperawatan, 7(1). 123133.

Horrigan, J. B. (2002). New internet user: what they do online, what they don't online and implications for the net's future. Pew Internet and American Life Project. 1-27.

Kaplan, A. M., \& Haenlein, M. (2010). User of the world, united! the challenges and opportunities of sosial media. Business Horizon, 53(1). 59-68.

Leleury, Z. A., Lesnussa, Y. P., Bension, J. B., \& Kakisina, Y. S. (2017). Analisis stabilitas model SIR (Susceptible, Infected, Recovered) pada penyebaran penyakit demam berdarah dengue di Provinsi Maluku. Jurnal Matematika, 7(2). 144-158.

Muna, F. M., \& Astuti, T. P. (2014). Hubungan antara kontrol diri dengan kecenderungan kecanduan media sosial pada remaja akhir. Empati, 3(4). 481-491.

Neuhauser, C. (2004). Calculus for biology and medicine. New Jersey: Pearson Education. 
Nurmandia, H., Wigati, D., \& Maslucha, L. (2013). Hubungan antara kemampuan sosialisasi dengan kecanduan jejaring sosial. Jurnal Penelitian Psikologi, 4 (2). 107-119.

Putra, R. T. (2011). Kestabilan lokal bebas penyakit model epidemi SEIR dengan kumpulan infeksi pada periode laten, infeksi dan sembuh. Rekayasa Sipil, 7 (1). 42-52.

Rochmawati, W. (2012). Perilaku pemanfaatan internet. Jurnal Libri-Net, 1(1). 1-19.

Side, S. (2013). Sistem dinamik. Makassar: Badan Penerbit UNM.

Side, S. (2015). A susceptible-infected-recovered model and simulation for transmission of tuberculosis. Jurnal American Scientific Publisher, 21(2). 137-139.

Side, S., \& Rangkuti, Y. M. (2013). Solusi numerik pemodelan matematika SIR dan SEIR untuk penularan demam berdarah dengan metode semi analitik di Sulawesi Selatan. Medan: Lembaga Penelitian Unimed.

Side, S., \& Rangkuti, Y. M. (2015). Pemodelan matematika dan solusi numerik untuk penularan demam berdarah. Medan: Perdana Publising.

Tu, P. N. V. (1994). Dynamical system: an introduction with applications in economics and biology. New York: Springer-Verlag.

Widiana, H. S., Retnowati, S., \& Hidayat, R. (2004). Kontrol diri dan kec enderungan internet. Indonesian Psychologycal Journal, 1(1). 6-16. 